\title{
Uusi näkökulma koulutuksen ja työelämän välisten suhteiden tutkimiseen
}

\begin{abstract}
Takala, Tuomas. 1983. Uusi näkökulma koulutuksen ja työelämän välisten suhteiden tutkimukseen. Aikuiskasvatus 3, 4. 174-177. - Artikkelissa esitellään sellaista tutkimusnäkökulmaa, jossa huomion kohteena ovat koulutuksen aiheuttamat muutokset työprosesseihin sisältyvässä ihmistenvälisessä interaktiossa ja muussa kommunikaatiossa. Tällaisia muutoksia tarkastellaan yhteydessä sosiaali- ja ammattiryhmien välisiin eroihin. Lisäksi käsitellään työmarkkinoilla tapahtuvia muutoksia.
\end{abstract}

Ruotsin virkamiesten ja toimihenkilöiden ammatillinen keskusjärjestö TCO on äskettäin julkaissut laajahkon raportin aiheesta " Voiko koulutus muuttaa työelämää?"' (TCO 1983). Raportti ei ole etupäässä koulutuspoliittinen kannanotto, vaan se on tarkoitettu "stimuloimaan tutkimusta" em. aiheesta. Tällaisen julkaisun aikaansaaminen on huomionarvoinen teko ammatilliselta järjestöltä - TCO:n kohdalla ei kuitenkaan yllättävä siksi että sen jäsenistä suuri osa työskentelee juuri koulutussektorilla. Raportti sisältää paitsi TCO:n koulutuspoliittisia suuntaviivoja, myös v. 1981 järjestetyssä seminaarissa esitettyjä asiantuntijapuheenvuoroja ja hahmoteltuja tutkimustehtäviä sekä aihetta koskevaa tutkimusta esittelevän ja ideoivan katsauksen.

Koulutuksen ja työelämän välisiin suhteisiin liittyvistä TCO:n kannanotoista ovat huomionarvoisia ainakin seuraavat: Ensinnäkin niissä todetaan että koulutus on tähän asti pyrkinyt pikemmin sopeutumaan työelämään kuin muuttamaan sitä. TCO:n mukaan tulisi koulutuspolitiikan painopiste nyt siirtää työelämän muuttamiseen, jolloin koulutus siis voisi edistää ammattiyhdistysliikkeen työelämää koskevien tavoitteiden toteutumista. Tätä kantaa perustellaan myös viittaamalla työmarkkinoiden "polarisoitumistendensseihin" - toisin sanoen siihen, että vaikka työprosessien spontaani kehitys edellyttää osalta työntekijöitä yhä enemmän ammattitaitoa ja koulutusta, suurelta osalta se edellyttää niitä entistä vähemmän. Polarisoitumiskehityksen muuttamiseksi TCO vaatii laaja-alaisempaa ja joustavammat jatkomahdollisuudet tarjoavaa ammatillista koulutusta, joka tekisi mahdolliseksi tieto- ja taitoerojen sekä valtaerojen suipistamisen työelämässä. Tähän liittyen vastustetaan kiinteiden ammattiryhmien monopoliasemaa työmarkkinoilla ja näiden asemien turvaamista jäykillä, muodollista koulutusta koskevilla pätevyyskriteereillä (eli ns. kredentialismia). TCO:n kanta poikkeaa siis selvästi ammatillisten järjestöjen perinteisestä toiminnasta ammattiryhmien työmarkkina-asemien suojaamiseksi.

\section{Sosiologisen näkökulman merkitys}

Edellämainittu vaatimus koulutuksen suuntaamisesta työelämän muuttamiseen on toki esitetty monissa muissakin yhteyksissä, eikä siihen sinänsä vielä sisälly tämän kirjoituksen otsikossa mainittua uutta tutkimusnäkökulmaa. Sekä TCO:n että muissa kannanotoissa on koulutuksen mahdollisia vaikutuksia työelämään tarkasteltu lähinnä vain sillä tasolla että työelämän muutoksiin suutautuva koulutus voidaan ottaa huomioon työmarkkinajärjestöjen ja yritysten päätöksenteossa. Tätä kautta esimerkiksi yhteistyöhön kasvattaminen voi johtaa ryhmätyön runsaampaan käyttöön työnorganisaatiossa tai laaja-alaisen ammatillisen koulutuksen lisääminen voi johtaa yksinkertaisten työtehtävien vähentämiseen.

Kuitenkin koulutus joka tapauksessa vaikuttaa työelämään myös muulla tavalla kuin edellämainitun kaltaisen päätöksenteon kautta. Tällaiset vaikutukset ovat nähdäkseni tutkimuksen kannalta kiinnostavampia, koska ne ovat vaikeammin havaittavia ja niihin on toistaiseksi kiinnitetty vain vähän huomiota. Edel- 
leen nämä vaikutukset ovat useissa tapauksissa kovin eri suuntaisia kuin em. TCO:n asettamat tai muut vastaavat tavoitteet työelämän muuttamiseksi, jolloin niiden tutkiminen on tästäkin syystä tärkeää.

Tarkoittamani uusi näkökulma tulee esiin TCO:n raporttiin sisältyvässä laajassa ja erittäin monipuolisessa katsauksessa, jonka on laatinut Tukholman opettajakorkeakoulussa tutkijana työskentelevä Donald Broady. Tavalla joka on joillekin suomalaisille koulutustutkijoille tuttu aiemmista julkaisuista (Broady 1978 ja 1981) Broadyn katsaus tuo esille ja pyrkii yhdistämään toisiinsa yhteiskuntatieteen eri tutkimustraditioiden (ennen kaikkea saksalaisen kvalifikaatiotutkimuksen ja ranskalaisen kulttuurisosiologisen tutkimuksen) käsitteitä ja konkreettisen tutkimuksen tuloksia sekä yhteiskuntatieteen ja kasvatustieteen ongelmanașetteluja ja tutkimustuloksia. Kyseessä ei tällöin ole tutkimuksiin viittaavien perustelujen hakeminen TCO:n esittämille tavoitteille, vaan katsaukseen sisältyy myös kriittistä arviointia TCO:n koulutuspolitiikasta. Broadyn esitys on erinomainen (ja harvinainen) esimerkki siitä, että "tutkimuksen ehdoilla"' tapahtuva tarkastelu voi liittyä läheisesti käytännön koulutuspoliittisiin kysymyksiin ja samalla avata keskustelua intressiryhmien ja virkamiesten perspektiiviä laajemmaksi.

Donald Broady korostaa makrososiologisen näkökulman tärkeyttä koulutuksen ja työelämän välisten suhteiden tutkimuksessa. Tämä merkitsee sitä, että pyrittäessä selittämään esimerkiksi yksilöiden välisiä eroja koulutushalukkuudessa ei pidä rajoittua tarkastelemaan vain yksilöiden ominaisuuksia yhteydessä erilaisiin "taustamuuttujiin", vaan on myös analysoitava itse näiden erojen olemassaoloa osana yhteiskunnan rakennetta ja koulutuksen asemaa tämän rakenteen uusintamisessa. On siis otettava huomioon myös koulutukseen osallistuvien edessä oleva yhteiskunnallinen tulevaisuus ja sitä koskevien odotusten vaikutukset opiskelumotivaatioon. Huomio kohdistuu koulutuspolitiikan kannalta selvästikin vaikeisiin kysymyksiin.

Näiden ajatusten taustalla ovat Broadyn katsauksessa etenkin ranskalaisen kultuurisosiologin Pierre Bourdieun teoreettiset kehittelyt ja konkreettiset tutkimustulokset, joista suurin osa on luettavissa vain ranskan kielellä (koulutustutkimuksen kannalta poikkeuksena varhainen teos Bourdieu \& Passeron 1977). Keskeiset käsitteet, joita Bourdieun tutkimuksista voi saada yksilöiden välisten koulutusero- jen ja yhteiskunnan rakenteen tarkasteluun ovat "positioiden"' ja "dispositioiden"' käsitteet. Näistä "'positioiden" käsite viittaa erilaisiin ammatti- ja statusasemiin joita yhteiskunnassa on, ja "dispositiot" puolestaan ovat positioita vastaavia yksilöiden erilaisia käyttäytymisvalmiuksia, jotka muodostuvat osaksi koulutuksen piirissä ja joiden perustalla yksilöt sijoittuvat eri positioihin yhteiskunnan rakenteessa. Toisin ilmaistuna kyse on siitä, että ihmiset pyrkivät koulutuksen kautta ja muilla keinoin erottumaan kulttuurisesti toisista ihmisistä (ryhmistä), mihin liittyvät paitsi statuserot, myös valta- ja tuloerot (tätä kulttuurista erottautumista on tarkasteltu etenkin teoksessa Bourdieu 1979). Tästä näkökulmasta esimerkiksi työntekijöiden halukkuus osallistua aikuiskoulutukseen on nähtävä yhteydessä heidän asemiinsa työnorganisaatiossa ja työn ulkopuoliseen elämäntapaansa sekä näihin molempiin liittyvään identiteettiin suhteessa muihin työntekijäryhmiin.

Edellä lyhyesti kuvatussa näkökulmassa on olennaista se, että voidaan tarkastella samanaikaisesti sekä koulutuksen mahdollisesti aiheuttamia muutoksia työprosesseissa että koulutuksen osuutta niiden status-, valta- ja tuloerojen uusintamisessa, jotka säilyvät työn sisältöjen muutoksista huolimatta. Pyrin seuraavassa konkretisoimaan sitä, millaisia kysymyksiä tästä näkökulmasta lähtevään tutkimukseen voisi sisältyä.

\section{Koulutuksen vaikutukset eri tyyppisissä työprosesseissa}

Tarkasteltaessa koulutuksen mahdollisia vaikutuksia työprosessien sisältöön on nähdäkseni tärkeää erottaa toisaalta sellaiset työprosessit, joissa on keskeistä työvälineiden käyttö (kuten perinteisessä teollisuustyössä), ja toisaalta sellaiset, jotka koostuvat etupäässä $i h$ mistenvälisestä interaktiosta ja muusta kommunikaatiosta (esimerkiksi hallinnollinen työ). Niiden välinen ero ei tietenkään ole absoluuttinen, niin kuin kommunikaatioteknologian käyttöönotto työelämässä osoittaa. Tämän varauksen mielessäpitäen voi ensinmainittuja työprosesseja nimittää teknis-taloudellisista ehdoista määräytyviksi ja jälkimmäisiä taas kulttuurisesti määräytyviksi työprosesseiksi. Erottelua voisi havainnollistaa yksityiskohtaisemmin tiedoilla siitä, missä määrin jonkin alan työprosessit ovat erilaisia toisaalta erilaisissa teknologisissa ja taloudellisissa oloissa ja toisaalta eri kulttuureissa. 
Koulutuksella on todennäköisesti vaikutuksia ennen kaikkea sellaisiin työprosesseihin, joita edellä nimitettiin kultuurisesti määräytyviksi. Niiden piirissä eivät ole tärkeitä niinkään tekniset tiedot ja taidot, vaan pikemmin käyttäytymisen "tyylit", jotka koostuvat puhetavasta, arvostuksista, itsetunnosta jne. (ks. Collins 1971). Tämän seikanhan jokainen yhteiskunta- tai kasvatustieteilijä voi havaita jo omassa työympäristössään. Vaikeammin havaittava - tai ainakin myönnettävä - seikka lienee esimerkiksi se, että Suomen lukioiden runsaassa vieraiden kielten opetuksessa ei työelämän kannalta olennaisin tulos ehkä olekaan itse kielitaito, vaan sen sijaan itsetunnon kohoaminen verrattuna niihin, jotka eivät lukiota käy, ja sen myötä paremmat mahdollisuudet sijoittua työelämässä pikemmin johtavaan kuin alistettuun asemaan.

Koulutuspoliittisen päätöksenteon kannalta kulttuurisesti määräytyvät työprosessit ovat siinä suhteessa ongelmattomia, että niiden kohdalla koulutuksen sisällön ja sen tuottamien valmiuksien vastaavuus "työelämän vaatimuksiin" nähden säilyy tietyissä rajoissa koulutussuunnittelun ennustekyvystä riippumatta, sitä mukaa kuin koulutuksessa muovautuneet käyttäytymistyylit siirtyvät työelämään. Kuitenkin tällainen tilanne on koulutukselliseen tasa-arvoon tähtäävien pyrkimysten kannalta ongelmallinen siksi, että erilaiset käyttäytymistyylit muodostuvat paitsi koulutuksessa, myös suurelta osin sosiaalisesta taustasta riippuen erilaisessa kotikasvatuksessa sekä erilaisissa nuorten vertaisryhmissä (tähän seikkaan viittaa Bourdieun käyttämä käsite "'kulttuurien pääoma"'). Käyttäytymistyylien ja sosiaalisen taustan välisiin yhteyksiin on syytä kiinnittää erityistä huomiota siksi, että valikoituminen ammatteihin ainakin palkkatyön piirissä tapahtuu muodollisesti koulutuksen eikä sosiaalisen taustan perusteella, mikä peittää em. yhteyksiä. Siten esimerkiksi USA:n työmarkkinoilla aiemmin vallinnut avoin rodullinen diskriminointi on paljolti voinut korvautua koulutukseen perustuvalla valikoinnilla, jonka tulos on olennaisesti entisen diskriminoinnin kaltainen (ks. Collins 1979).

\section{Työn sisällön muutosten yhteydet koulutuspolitiikkaan}

Silloin kun työprosessien sisältönä ovat ennen kaikkea ihmistenvälinen interaktio ja muu kommunikaatio voidaan tämän sisällön muu- toksia siis tarkastella koulutuksen välityksellä syntyvänä tuloksena sosiaali- ja ammattiryhmien pyrkimyksestä statuksen, vallan ja tulojen lisäämiseen tai ainakin ylläpitämiseen suhteessa muihin ryhmiin. Suomessa on esimerkiksi todettu, että viime aikoina on paljon kaupallisen alan ammatillisen koulutuksen saaneita sijoittunut sellaisiin työtehtäviin, joihin aiemmin siirryttiin yleisesti pelkän keskikoulun pohjalta. On kuitenkin syytä kysyä, missä suhteessä nämä työt ovat tällöin pysyneet samoina kuin ennen ja missä suhteessa enemmän koulutettujen tulo niihin on muuttanut niitä uudenlaisiksi. Sikäli kuin työprosessien sisällöt muuttuvat on koulutuksen ja siihen valmistavan kotikasvatuksen suhteen huono-osaisten vaikea selviytyä ao. töiden edellyttämästä interaktiosta ja muusta kommunikaatiosta. Koulutuksesta työelämään siirtyvät tuskin näkevät tämänkaltaisia tilanteita kulttuurisesti ehdollisina, vaan kokevat että valikoituminen ammatteihin koulutuksen perusteella on itse työprosesseista johtuva välttämättömyys. Yksilöiden välisessä kilpailutilanteessa tämä todennäköisesti johtaa pyrkimykseen hankkia lisää koulutusta.

Koulutuksen vaikuttaessa ihmistenväliseen interaktioon ja muuhun kommunikaatioon työn piirissä on ilmeisen ongelmallista puhua tällaisissa tapauksissa liikakvalifikaatiosta ja liikakoulutuksesta. Ei nimittäin ole ilman muuta selvää, mikä on tällöin vertailukohtana "liiasta" puhuttaessa. Mutta tämä ei tarkoita etteikö siitä voisi lainkaan puhua: jos koulutuksen laajeneminen johtuu suurelta osin pyrkimyksestä kulttuuriseen erottautumiseen ja käyttäytymistyylien hankkimiseen, ei tällainen periaatteessa loputon kierre tietenkään ilman muuta ole koulutettavien itsensä kannalta positiivista. Toinen koulutuspoliittien keskustelun kannalta tärkeä seikka on se, että myös itseisarvoiseksi nimitetty ja koettu koulutus saattaa uudesta näkökulmasta osoittautua keinoksi kulttuuriseen erottautumiseen.

Edelläkuvatun kaltaisiin työn sisältöjen muutoksiin saattaa liittyä niitä vahvistavia ja koulutuspolitiikan kannalta merkittäviä muutoksia työmarkkinoilla. Näitä muutoksia on tutkinut yhdysvaltalainen Randall Collins (1979), jonka tarkastelutapaan ovat keskeisesti vaikuttaneet paitsi Bourdieun, myös Max Weberin ajatukset. Työprosessien muutosten ohella ja osaksi niiden ansiosta syntyy eri ammattiryhmille mahdollisuuksia omien intressiensä ajamiseen työmarkkinoilla ja koulutuspolitiikassa. Näiden intressien turvaamiseen pyritään vaatimalla tietyn muodollisen koulu- 
tuksen asettamista tiukaksi pätevyyskriteeriksi tiettyihin työtehtäviin - siis asetelma, jota alussa mainituissa TCO:n kannanotoissa arvosteltiin. Samalla muodollinen koulutus on nykyisin, etenkin palvelualoilla, työnantajien kannalta yleensä eräs keskeinen työhönottokriteeri. Koulutuksen merkitys voi tällöin eri tapauksissa olla erilainen ja analyyttisesti voidaan erottaa ainakin kolme vaihtoehtoa:

1) koulutuksen antamat tekniset tiedot ja taldot ovat tarpeen ao. työtehtävien suorittamiseksi,

2 ) koulutus on epärelevantti itse työtehtävien kannalta, mutta on muuten käyttökelpoinen tapa valinnan suorittamiseksi työnhakijoiden joukosta,

3) kahden edellämainitun väliin sijoittuva vaihtoehto, jossa koulutus on työn kannalta relevantti pikemmin käyttäytymistyylien muodostajana kuin teknisluontoisten valmiuksien antajana.

Tässä kirjoituksessa käsiteltävän näkökulman kannalta ovat keskeisiä viimeksimainitun vaihtoehdon tapaukset, joissa koulutuksen käyttö työmarkkinoilla valintakriteerinä ilmeisestikin aiheuttaa samanlaista painetta koulutuksen laajentamiseen kuin itse työprosessien muutokset.
Elinkeinorakenne on Suomessa ja muissa teollistuneissa maissa muuttunut siten, että palvelualojen osuus on kasvanut. Elinkeinorakenteen muutos merkitsee sitä, että edelläkuvatun kaltaiset koulutuksen vaikutukset työn sisältöihin ja niihin liittyvät työmarkkinaprosessit koskettavat hyvin suurta osaa koulutuksesta työelämään siirtyviä. Vastaavasti on kasvanut myös näitä vaikutuksia tarkastelevan tutkimusnäkökulman merkitys.

\section{Lähteet}

Bourdieu, P. 1979. La distinction - critique sociale du jugement. Paris: Editions de Minuit.

Bourdieu, P. \& Passeron, J-C. 1977. Reproduction in Education, Society and Culture. London: Sage.

Broady, D. 1978. Utbildning och politisk ekonomi. Högskolan för lärärutbildning. Institutionen för pedagogik. Forskningsgruppen för läroplansteori och kulturreproduktion. Rapport 1.

Broady, D. 1981. Den dolda läroplanen. Stockholm: Symposion.

Collins, R. 1971. Functional and Conflict Theories of Educational Stratification. American Sociological Review 36, 1002-1019.

Collins, R. 1979. The Credential Society. London: Academic Press.

TCO. 1983. Kan utbildning förändra arbetslivet? Örebro. 